\title{
Tilakohtainen kasvihuonekaasupäästöjen laskenta Taloustohtorissa
}

\author{
Mika Sulkava ${ }^{1}$, Arto Latukka $^{1)}$, Aleksi Lehtonen ${ }^{2)}$, Sanna Pitkänen ${ }^{3)}$, Kristiina Regina ${ }^{3)}$ ja \\ Olli Salminen ${ }^{4)}$ \\ ${ }^{1)}$ Luke, Tilastopalvelut, PL 1003, 00581 Helsinki, mika.sulkava(at)luke.fi, arto.latukka(at)luke.fi \\ ${ }^{2)}$ Luke, Luonnonvarat ja biotuotanto, Jokiniemenkuja 1, 01370 Vantaa, aleksi.lehtonen(at)luke.fi \\ ${ }^{3)}$ Luke, Luonnonvarat ja biotuotanto, Tietotie 4, 31600 Jokioinen, sanna.pitkanen(at)luke.fi, \\ kristiina.regina(at)luke.fi \\ ${ }^{4)}$ Luke, Talous ja yhteiskunta, Jokiniemenkuja 1, 01370 Vantaa, olli.salminen(at)luke.fi
}

\section{TIIVISTELMÄ}

Maatalouden tuottamat kasvihuonekaasupäästöt raportoidaan YK:n Ilmastosopimuksen ja Kioton pöytäkirjan mukaisesti osana Suomen kokonaispäästöjä. Yhteensä kaikki maatalousperäiset päästöt ovat noin $20 \%$ Suomen kokonaispäästöistä. Hallitustenvälisen ilmastonmuutospaneelin IPCC:n ohjeiden mukainen päästölaskenta on rakennettu niin, että metsätaloutta, maataloutta ja tilojen energiankäyttöä tarkastellaan erillään toisistaan. Raportointisektorit ylittävä tarkastelu mahdollistaisi maatilan tarkastelun kokonaisuutena. Tilan omistaja on paras asiantuntija valitsemaan toteuttamiskelpoiset päästövähennystoimet omalla tilallaan. Tähän mennessä ei kuitenkaan ole ollut mahdollista arvioida tilannetta ja tehtyjen toimien vaikuttavuutta tilakohtaisesti.

Luonnonvarakeskuksen (Luke) Taloustohtori-verkkopalvelu (www.luke.fi/taloustohtori) tarjoaa suuren määrän kannattavuuskirjanpitotilojen tietojen pohjalta laskettuja maa- ja puutarhatalousyritysten tulostietoja. Tässä MMM:n rahoittamassa hankkeessa rakennetaan Luken Taloustohtorijärjestelmään verkkopalvelu, joka antaa kannattavuuskirjanpitotiloille mahdollisuuden tarkastella oman tilan kasvihuonekaasulaskelmia, verrata tuloksia eri tilaryhmien keskiarvotuloksiin sekä arvioida vaihtoehtoisten toimintatapojen vaikutuksia. Uusi verkkopalvelu sisältää maatalouden, puutarhatalouden sekä soveltuvasti myös metsätalouden ja näihin liittyvän energiankäytön.

Kannattavuuskirjanpitotiloille lasketaan maatalouden kasvihuonekaasulaskentatulokset taannehtivasti vuodesta 2000 lähtien. Kannattavuuskirjanpidon raportointijärjestelmillä nämä tulokset painotetaan yleistettäväksi alueellisiksi keskiarvo- ja kokonaistuloksiksi, joten verkkopalvelu tarjoaa tietoa kaikille maatiloille ja myös maatalouspoliittiselle päätöksenteolle. Myös päästövähennysten taloudellisten vaikutusten tarkastelua voidaan kehittää, koska kannattavuuskirjanpitoaineisto sisältää sekä taloustiedot että tuotantotiedot.

Kasvihuonekaasupäästöjen laskenta tapahtuu automaattisesti lennossa SAS-ohjelmistossa. Suurin osa laskennassa tarvittavista tiedoista on Taloustohtorin tietokannassa. Tilojen puustovarannot ja metsän kasvu lasketaan Luken NettiMELA-palvelussa. Kasvihuonekaasujen laskenta noudattaa IPCC:n 2006 Guidelines -ohjeistoa ja rakennetaan yhdenmukaiseksi Suomen kasvihuonekaasuinventaariossa käytettävien menetelmien kanssa. Kasvihuonekaasuinventaariossa käytettyjä menetelmiä yksinkertaistetaan hieman esimerkiksi käyttämällä keskiarvotietoja tietystä päästölähteestä perustuen raportoituihin päästöihin, jotta järjestelmän ylläpitotyömäärä pysyy kohtuullisena. Näin myöskään laskennassa tarvittava tietomäärä ei nouse kohtuuttoman suureksi.

Laskennan lopputuloksena raportoidaan sekä tilakohtaisesti että alueellisesti 1. metaanipäästöt tuotantoeläimistä ja lannasta, 2. dityppioksidipäästöt lannasta ja maaperästä, 3. hiilidioksidipäästöt kalkituksesta, 4. hiilidioksidipäästöt ja -nielut biomassasta ja maaperästä. 5. hiilidioksidipäästöt maatilan energiankäytöstä.

Asiasanat: kasvihuonekaasu, hiilidioksidi, metaani, dityppioksidi, maatila, kannattavuus, kirjanpito 


\section{Johdanto}

Maatalouden tuottamat kasvihuonekaasupäästöt raportoidaan YK:n Ilmastosopimuksen ja Kioton pöytäkirjan mukaisesti osana Suomen kokonaispäästöjä. Yhteensä kaikki maatalousperäiset päästöt ovat noin $20 \%$ Suomen kokonaispäästöistä. Hallitustenvälisen ilmastonmuutospaneelin IPCC:n ohjeiden mukainen päästölaskenta on rakennettu niin, että metsätaloutta, maataloutta ja tilojen energiankäyttöä tarkastellaan erillään toisistaan. Raportointisektorit ylittävä tarkastelu mahdollistaisi maatilan tarkastelun kokonaisuutena.

Tilan omistaja on paras asiantuntija valitsemaan toteuttamiskelpoiset päästövähennystoimet omalla tilallaan. Tähän mennessä ei kuitenkaan ole ollut mahdollista arvioida tilannetta ja tehtyjen toimien vaikuttavuutta tilakohtaisesti. Tässä artikkelissa esitellään maatilakohtainen kasvihuonekaasupäästöjen laskentajärjestelmä, joka rakennetaan osaksi Luonnonvarakeskuksen (Luke) Taloustohtoriverkkopalvelua. Järjestelmän avulla on mahdollista laskea kasvihuonekaasupäästöt Taloustohtorin laskennan pohjana oleville kannattavuuskirjanpitotiloille.

Artikkelin loppuosan rakenne on seuraavanlainen: seuraavassa osassa esitellään kannattavuuskirjanpitoaineisto, Taloustohtori sekä kasvihuonekaasulaskennan perusperiaatteet, kolmannessa osassa esitetään laskennan tuloksia ja viimeisessä osassa johtopäätöksiä.

\section{Aineisto ja menetelmät}

\section{Kannattavuuskirjanpitoaineisto ja muut aineistot}

Suomen maa- ja puutarhatalousyritysten kannattavuutta kuvaavat luvut lasketaan vuosittain Luken kannattavuuskirjanpidon perusteella. Nämä kannattavuusluvut kuvaavat noin 60000 yrityksen keskimääräisiä tuloksia. Tilojen kannattavuutta tarkkaillaan noin 1000 tilan otoksen avulla. Tässä työssä käytetään vuosien 2000-2013 aineistoa. Kannattavuuskirjanpidon alkuperäisenä tavoitteena on ollut edustaa 40000 Suomen suurinta tilaa, ja tämän vuoksi otoksessa on melko vähän pieniä tiloja. Alueellisten kasvihuonekaasupäästöjen laskennan kannalta tällä ei ole suurta merkitystä pienten tilojen tyypillisesti pienten päästöjen sekä otospainojen kalibroinnin (Sulkava ym., 2015) takia.

Kannattavuuskirjanpitoaineistoon kerätään tiloilta tuhansia muuttujia. Tässä työssä tarvittavista muuttujista suurin osa on olemassa kirjanpitoaineistossa jo valmiiksi. Keskeisiä laskennassa tarvittavia muuttujia ovat tilan eläinten lukumäärät, viljelykasvien tuotantomäärät, orgaanisten ja epäorgaanisten maiden pinta-alat sekä koneiden käyttämiseen ja rakennusten lämmittämiseen käytettyjen polttoaineiden määrät. Polttoaineiden määristä ei ole kaikilta tiloilta saatavissa tietoa suoraan, vaan määrät joudutaan laskemaan tilan polttoainekustannuksista käyttäen polttoaineiden keskimääräisiä hintoja. Latukka (1998) ja Community Committee for the Farm Accountancy Data Network (2009) tarjoavat tarkempaa tietoa kannattavuuskirjanpidon muuttujista.

Joitain lisätietoja joudutaan kuitenkin hankkimaan muista lähteistä. Tilojen metsissä tehdyt hakkuut ja puustovaranto ovat esimerkiksi merkittäviä tekijöitä hiilitaseen laskennassa, ja nämä tiedot joudutaan hankkimaan erikseen metsänomistajilta ja metsäsuunnitelmista. Lisäksi tiloilla käytössä oleva lannankäsittelyjärjestelmä vaikuttaa päästöihin, mutta lannankäsittelyjärjestelmistä on kirjanpitoaineistossa vain epävarmaa tietoa. Tämän vuoksi tämä tieto tullaan jatkossa keräämään kirjanpitotiloilta suuremmalla tarkkuudella. Tietoa keinolannoitteiden käyttömääristä tiloilla aletaan kerätä vuodesta 2016 lähtien.

\section{Taloustohtori}

Luken Taloustohtori-verkkopalvelu (www.luke.fi/taloustohtori) tarjoaa suuren määrän kannattavuuskirjanpitotilojen tietojen pohjalta laskettuja maa- ja puutarhatalousyritysten tulostietoja. Taloustohtorissa on myös runsaasti muunkinlaista alkutuotantoon, kuten rannikkokalastukseen sekä poro- ja mehiläistalouteen liittyvää tietoa. Tässä artikkelissa esiteltävässä Maa- ja metsätalousministeriön rahoittamassa hankkeessa rakennetaan vuosien 2015-2016 aikana Taloustohtori-järjestelmään verkkopalvelu, joka antaa kannattavuuskirjanpitotiloille mahdollisuuden tarkastella oman tilan kasvihuonekaasulaskelmia, verrata tuloksia eri tilaryhmien keskiarvotuloksiin sekä arvioida vaihtoehtoisten toimintatapojen vaikutuksia. Uusi verkkopalvelu sisältää maatalouden, puutarhatalouden sekä soveltuvasti myös metsätalouden ja näihin liittyvän energiankäytön. 
Taulukko 1. Taloustohtorin kasvihuonekaasulaskenta-palvelussa laskettavat päästölajit.

Päästölaji

1 Metaanipäästöt tuotantoeläimistä ja lannasta

2 Dityppioksidipäästöt lannasta ja maaperästä

3 Hiilidioksidipäästöt kalkituksesta

4 Hiilidioksidipäästöt ja -nielut biomassasta ja maaperästä

5 Hiilidioksidipäästöt maatilan energiankäytöstä

\section{Kasvihuonekaasupäästöjen laskenta}

Kannattavuuskirjanpitotiloille lasketaan maatalouden kasvihuonekaasulaskentatulokset taannehtivasti vuodesta 2000 lähtien. Kannattavuuskirjanpidon raportointijärjestelmillä nämä tulokset painotetaan yleistettäväksi alueellisiksi keskiarvo- ja kokonaistuloksiksi, joten verkkopalvelu tarjoaa tietoa kaikille maatiloille ja myös maatalouspoliittiselle päätöksenteolle. Myös päästövähennysten taloudellisten vaikutusten tarkastelua voidaan kehittää, koska kannattavuuskirjanpitoaineisto sisältää sekä taloustiedot että tuotantotiedot. Laskennan lopputuloksena raportoidaan sekä tilakohtaisesti että alueellisesti taulukossa 1 esitetyt päästölajit.

Kasvihuonekaasupäästöjen laskenta tapahtuu automaattisesti lennossa SAS-ohjelmistossa. Suurin osa laskennassa tarvittavista tiedoista on Taloustohtorin tietokannassa. Tilojen puustovarannot ja metsän kasvu lasketaan Luken NettiMELA-palvelussa. Kasvihuonekaasujen laskenta noudattaa IPCC:n 2006 Guidelines -ohjeistoa (IPCC, 2006), ja laskenta rakennetaan yhdenmukaiseksi Suomen kasvihuonekaasuinventaariossa käytettävien menetelmien kanssa. Kasvihuonekaasuinventaariossa käytettyjä menetelmiä yksinkertaistetaan hieman esimerkiksi käyttämällä keskiarvotietoja tietystä päästölähteestä perustuen raportoituihin päästöihin, jotta järjestelmän ylläpitotyömäärä pysyy kohtuullisena. Näin myöskään laskennassa tarvittava tietomäärä ei nouse kohtuuttoman suureksi.

\section{Tulokset ja tulosten tarkastelu}

Projektin ensimmäisen vuoden aikana on rakennettu Taloustohtoriin käyttöliittymää uudelle palvelulle. Palvelun esimerkkituloksia esitellään kuvissa 1 ja 2. Esimerkkituloksissa on palvelun testaamiseen käytetylle aineistolle laskettuja tuotantoeläinten metaanipäästöjä.

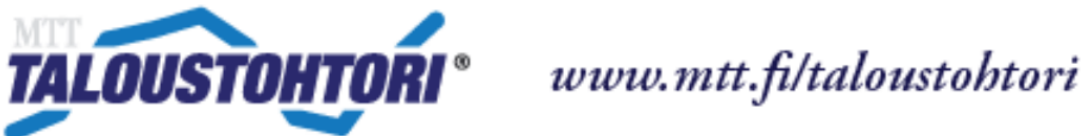

Taloustohtori. Kasvihuonekaasulaskenta-palvelu (luke.fi/taloustohtori). Aineisto: kasvihuonekaasulaskentaaineisto. 14.12.2015

\begin{tabular}{|c|c|c|c|c|c|c|c|c|c|c|c|c|c|c|}
\hline $\begin{array}{c}\text { Kasvihuonekaasut ruuansulatus } \\
\text { naudat }\end{array}$ & 2013 & 2012 & 2011 & 2010 & 2009 & 2008 & 2007 & 2006 & 2005 & 2004 & 2003 & 2002 & 2001 & 2000 \\
\hline $\mathrm{CH} 4$ emissions for dairy cows & 44,87 & 44,70 & 44,93 & 45,57 & 45,12 & 44,64 & 45,59 & 46,83 & 47,61 & 48,30 & 48,90 & 50,10 & 50,25 & 50,75 \\
\hline $\mathrm{CH} 4$ emissions for suckler cows & 6,20 & 6,27 & 6,33 & 6,09 & 5,57 & 5,17 & 4,59 & 4,11 & 3,63 & 3,26 & 2,92 & 2,91 & 2,80 & 2,85 \\
\hline $\mathrm{CH} 4$ emissions for bulls (over 1 year) & 8,39 & 8,33 & 8,61 & 8,93 & 8,40 & 8,29 & 8,36 & 8,40 & 7,96 & 8,17 & 8,37 & 8,13 & 7,58 & 7,65 \\
\hline $\mathrm{CH} 4$ emissions for heifers & 8,65 & 8,60 & 8,79 & 8,89 & 8,69 & 8,75 & 8,78 & 8,89 & 8,71 & 8,93 & 9,08 & 9,01 & 8,93 & 8,95 \\
\hline $\mathrm{CH} 4$ emissions for calves (under 1 year) & 11,17 & 11,32 & 11,25 & 11,40 & 11,22 & 11,14 & 11,29 & 11,32 & 11,59 & 11,63 & 11,89 & 12,02 & 12,06 & 11,94 \\
\hline $\mathrm{CH} 4$ emissions for dairy cattle & 44,87 & 44,70 & 44,93 & 45,57 & 45,12 & 44,64 & 45,59 & 46,83 & 47,61 & 48,30 & 48,90 & 50,10 & 50,25 & 50,75 \\
\hline $\mathrm{CH} 4$ emissions for non-dairy cattle & 34,42 & 34,51 & 34,99 & 35,31 & 33,88 & 33,35 & 33,02 & 32,73 & 31,89 & 31,99 & 32,25 & 32,06 & 31,36 & 31,39 \\
\hline Total emissions for cattle & 79,29 & 79,21 & 79,91 & 80,88 & 79,00 & 77,98 & 78,60 & 79,55 & 79,49 & 80,29 & 81,15 & 82,17 & 81,61 & 82,14 \\
\hline
\end{tabular}

Palvelun tuottaa: Suomen Luonnonvarakeskus, Luke | www.luke.fi

Kuva 1. Esimerkki Taloustohtorin kasvihuonekaasulaskenta-palvelun nautojen metaanipäästöjen tuloksista. Kuvassa on erityyppisten nautojen metaanipäästöjä vuosilta 2000-2013 testiaineiston perusteella laskettuna. Lukujen yksiköillä ja suuruuksilla ei ole tässä esimerkissä maatilakohtaista tulkintaa. 


\section{TALOUSTOHTORI ${ }^{\circ}$ www.mtt.filtaloustohtori}

Taloustohtori. Kasvihuonekaasulaskenta-palvelu (luke.fi/taloustohtori). Aineisto: kasvihuonekaasulaskenta-aineisto. 14.12.2015

\begin{tabular}{|c|c|c|c|c|c|c|c|c|c|c|c|c|c|c|}
\hline $\begin{array}{l}\text { Kasvihuonekaasut ruuansulatus } \\
\text { muut eläimet }\end{array}$ & 2013 & 2012 & 2011 & 2010 & 2009 & 2008 & 2007 & 2006 & 2005 & 2004 & 2003 & 2002 & 2001 & 2000 \\
\hline $\mathrm{CH} 4$ emissions for sheep & 1,14 & 1,09 & 1,08 & 1,05 & 0,99 & 1,03 & 1,00 & 0,98 & 0,74 & 0,81 & 0,72 & 0,70 & 0,68 & 0,71 \\
\hline $\mathrm{CH} 4$ emissions for swine & 1,31 & 1,30 & 1,34 & 1,39 & 1,40 & 1,49 & 1,50 & 1,42 & 1,42 & 1,38 & 1,37 & 1,30 & 1,25 & 1,33 \\
\hline $\mathrm{CH} 4$ emissions for sows & 0,45 & 0,47 & 0,50 & 0,53 & 0,53 & 0,59 & 0,61 & 0,60 & 0,62 & 0,60 & 0,61 & 0,59 & 0,55 & 0,63 \\
\hline $\mathrm{CH} 4$ emissions for piglets & 0,05 & 0,05 & 0,05 & 0,05 & 0,05 & 0,06 & 0,06 & 0,06 & 0,06 & 0,06 & 0,06 & 0,05 & 0,05 & 0,05 \\
\hline $\mathrm{CH} 4$ emissions for fattening pigs & 0,60 & 0,58 & 0,58 & 0,60 & 0,60 & 0,61 & 0,60 & 0,54 & 0,54 & 0,52 & 0,51 & 0,46 & 0,45 & 0,45 \\
\hline $\mathrm{CH} 4$ emissions for boars & 0,01 & 0,01 & 0,01 & 0,01 & 0,01 & 0,01 & 0,01 & 0,01 & 0,02 & 0,02 & 0,02 & 0,02 & 0,02 & 0,02 \\
\hline $\mathrm{CH} 4$ emissions for veaned pigs & 0,20 & 0,19 & 0,20 & 0,20 & 0,21 & 0,22 & 0,21 & 0,20 & 0,19 & 0,18 & 0,18 & 0,18 & 0,18 & 0,18 \\
\hline $\mathrm{CH} 4$ emissions for goats & 0,02 & 0,02 & 0,02 & 0,02 & 0,03 & 0,03 & 0,03 & 0,03 & 0,03 & 0,04 & 0,03 & 0,03 & 0,04 & 0,04 \\
\hline $\mathrm{CH} 4$ emissions for horses & 1,16 & 1,17 & 1,18 & 1,16 & 1,13 & 1,09 & 1,07 & 1,04 & 1,01 & 0,97 & 0,95 & 0,94 & 0,93 & 0,91 \\
\hline $\mathrm{CH} 4$ emissions for ponies & 0,19 & 0,19 & 0,18 & 0,17 & 0,17 & 0,16 & 0,15 & 0,14 & 0,14 & 0,13 & 0,13 & 0,13 & 0,12 & 0,12 \\
\hline $\mathrm{CH} 4$ emissions for horses and ponies & 1,35 & 1,36 & 1,36 & 1,34 & 1,30 & 1,25 & 1,22 & 1,19 & 1,15 & 1,10 & 1,08 & 1,06 & 1,05 & 1,03 \\
\hline $\mathrm{CH} 4$ emissions for poultry & 0,00 & 0,00 & 0,00 & 0,00 & 0,00 & 0,00 & 0,00 & 0,00 & 0,00 & 0,00 & 0,00 & 0,00 & 0,00 & 0,00 \\
\hline $\mathrm{CH} 4$ emissions for reindeer & 3,81 & 3,82 & 3,91 & 3,85 & 3,84 & 3,89 & 3,85 & 3,94 & 4,12 & 4,00 & 3,91 & 3,97 & 3,70 & 4,05 \\
\hline $\mathrm{CH} 4$ emissions for minks and fitches & 0,14 & 0,14 & 0,11 & 0,16 & 0,13 & 0,13 & 0,18 & 0,14 & 0,15 & 0,14 & 0,14 & 0,14 & 0,14 & 0,15 \\
\hline $\mathrm{CH} 4$ emissions for foxes and racoons & 0,20 & 0,20 & 0,18 & 0,19 & 0,21 & 0,14 & 0,17 & 0,20 & 0,23 & 0,22 & 0,22 & 0,20 & 0,15 & 0,19 \\
\hline $\mathrm{CH} 4$ emissions for fur animals & 0,34 & 0,34 & 0,29 & 0,35 & 0,34 & 0,27 & 0,35 & 0,34 & 0,38 & 0,35 & 0,36 & 0,34 & 0,29 & 0,34 \\
\hline Total emissions for other livestock & 7,97 & 7,93 & 8,01 & 8,00 & 7,90 & 7,95 & 7,95 & 7,90 & 7,84 & 7,67 & 7,48 & 7,42 & 7,01 & 7,49 \\
\hline
\end{tabular}

Palvelun tuottaa: Suomen Luonnonvarakeskus, Luke | www.luke.fi

Kuva 2. Esimerkki Taloustohtorin kasvihuonekaasulaskenta-palvelun muiden eläinten ruoansulatuksen metaanipäästöjen tuloksista. Kuvassa on eri eläinlajien metaanipäästöjä vuosilta 2000-2013 testiaineiston perusteella laskettuna. Lukujen yksiköillä ja suuruuksilla ei ole tässä esimerkissä maatilakohtaista tulkintaa.

Kuvan 1 luvut ovat eri nautaluokkien päästöjä ja kuvan 2 luvut muiden tuotantoeläinten päästöjä. Nautojen kasvihuonepäästöt ovat kokonaisuuden kannalta niin merkittäviä, että erityyppisten nautojen päästöt on perusteltua eritellä yksityiskohtaisemmin kuin muiden tuotantoeläinten päästöt.

Eläinten metaanipäästöjen laskennan saattamisessa Taloustohtorissa tilatasolle pitää vielä ratkaista muun muassa se, miten taulukoissa 1 ja 2 käytetty IPCC:n eläinluokittelu vastaa parhaiten kannattavuuskirjanpidossa käytettävää hieman erilaista eläinten luokittelua. Muiden taulukon 1 päästölajien osalta SAS-laskentarutiinien implementointi on käynnissä tätä kirjoitettaessa.

\section{Johtopäätökset}

Kannattavuuskirjanpitoaineiston ja muutamien lisämuuttujien avulla on mahdollista laskea kirjanpitotilojen kasvihuonekaasupäästöjä. IPCC:n ja kannattavuuskirjanpidon välillä on pieniä eroavaisuuksia muun muassa eläinten luokittelussa. Tästä huolimatta laskenta saataneen tehtyä kirjanpitoaineistoon ja IPCC:n laskentamenetelmiin pohjautuen hyvällä tarkkuudella. Tällä hetkellä tuotantoeläinten metaanipäästöjen laskenta on viimeistelyä vaille valmis. Muiden päästökomponenttien laskeminen, tilaryhmien väliset vertailut ja ajallisen kehityksen tutkiminen ovat tutkimusaiheita vuonna 2016, kun verkkopalvelua rakennetaan valmiiksi. 


\section{Kirjallisuus}

Community Committee for the Farm Accountancy Data Network, 2009. Typology handbook, Tech. Rep. RI/CC 1500 rev. 3, European Commission - Directorate-General for Agriculture and Rural Development.

IPCC 2006. 2006 IPCC Guidelines for National Greenhouse Gas Inventories, 2006, Prepared by the National Greenhouse Gas Inventories Programme, Eggleston H.S., Buendia L., Miwa K., Ngara T. and Tanabe K. (eds). Published: IGES, Japan.

Latukka, A. 1998. Maatalousyritysten tulorahoituksen riittävyyden ennustaminen neuroverkkomenetelmällä, lisensiaatintutkimus, Helsingin yliopisto, Taloustieteen laitos, Julkaisuja nro 22, Maatalouden liiketaloustiede.

Sulkava, M., Sepponen, A-M., Yli-Heikkilä, M., Latukka, A. 2015. Clustering of the self-organizing map reveals profiles of farm profitability and upscaling weights. Neurocomputing, 147:197-206, January 2015. 